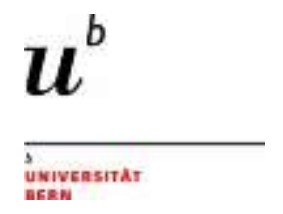

\title{
An Assessment of the Potential Economic Impacts of RCEP on Vietnam Automobile Sector
}

Tu Thuy Anh

Foreign Trade University (FTU), Vietnam

thuyanh.tu@ftu.edu.vn

\section{Le Minh Ngoc}

Foreign Trade University (FTU), Vietnam

ngoc.le@ftu.edu.vn

\section{Nguyễn Quỳnh Hương \\ Foreign Trade University}

huongntq.2010@gmail.com

This research aims at examining impacts of ASEAN+6 trade agreements on automobile industry in Vietnam. Vietnam automobile industry competes with Thailand, Indonesia and those ASEAN countries as well as China, Korea, Japan and those assigned with ASEAN agreement. By 2018, the automobile import tariff from China, Korea and Japan will reduced to $5 \%$. In the context of multiple trade agreements, the study of automobile industry has recently become an interesting topic, especially for the policy debate.

Research for this paper was funded by the Swiss State Secretariat for Economic Affairs under the SECO / WTI Academic Cooperation Project, based at the World Trade Institute of the University of Bern, Switzerland. 


\title{
AN ASSESSMENT OF THE POTENTIAL ECONOMIC IMPACTS OF RCEP ON VIETNAM AUTOMOBILE SECTOR ${ }^{1}$
}

\author{
TU Thuy Anh ${ }^{2}$ \\ LE Minh $\mathrm{Ngoc}^{3}$

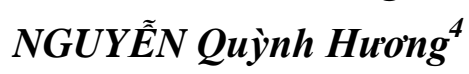

\section{Introduction}

\subsection{Overview of Vietnam automobile market and import}

The formation of automobile market in Vietnam was relatively late compared to the world. In 1986, Vietnam kicked off the Renovation initiative. Along with political and economic reform efforts of the country, relations with capitalist countries have been gradually resumed, which facilitated the automobile market in Vietnam become more dynamic with various types of automobiles from different foreign branch names such as Toyota, Ford, Honda, Mercedes Benz, etc.

The automobile market in Vietnam has two major segments: Completely Knocked Down (CKD) and Completely Build Up (CBU). A CKD vehicle means a vehicle is assembled locally using all the major parts, components, and technology imported from the country of its origin. A CBU import means a vehicle is completely built out of the country. If a vehicle is tagged as $\mathrm{CBU}$ import, it means the vehicle is imported to the country as a whole piece.

Generally speaking, the localization ratio of Vietnam automobile industry is still very low. Thus, importation of both final and intermediate products related to automobile manufacture plays a very important role. For Vietnam, value of trade in automobile products accounts for a good proportion in total value of trade in commodities. According to Trade $\mathrm{Map}^{5}$ database, in 2015, products in the $\mathrm{HS}^{6} 87$ group (Vehicles other than railway, tramway) ranks at the $6^{\text {th }}$ among the top 10 product groups with highest import value.

\footnotetext{
${ }^{1}$ The authors would like to thank WTI/SECO for funding this research. This paper was presented at the Vietnam Economist Annual Meeting (VEAM 2016) organized in Da Nang on 11 and 12 August 2016.

${ }^{2}$ Foreign Trade University, 91, Chua Lang, Dong Da, Ha Noi, Vietnam. Email: thuyanh.tu@ftu.edu.vn.

${ }^{3}$ Foreign Trade University, 91, Chua Lang, Dong Da, Ha Noi, Vietnam. Email: ngoc.le@ ftu.edu.vn.

${ }^{4}$ Foreign Trade University, 91, Chua Lang, Dong Da, Ha Noi, Vietnam. Email: huongntq.2010@ gmail.com.

${ }^{5}$ http://www.trademap.org/

${ }^{6}$ Harmonized System.
} 
Figure 1: Import values of top 10 products imported by Viet Nam

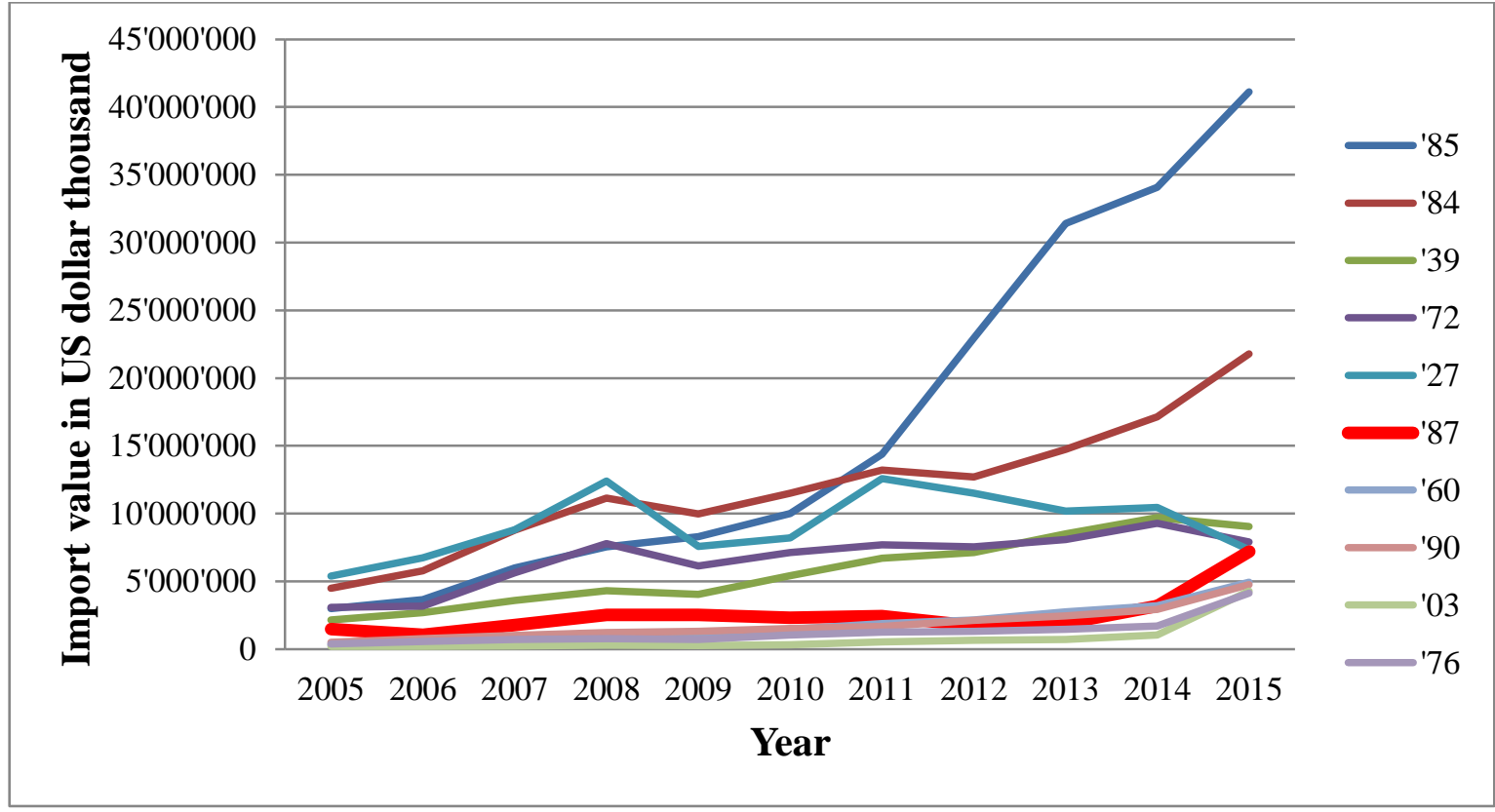

Source: Authors' compilation from Trade Map database

Figure 2: Top 10 supplying markets for the product group HS - 87 (Vehicles other than railway, tramway) imported by Vietnam

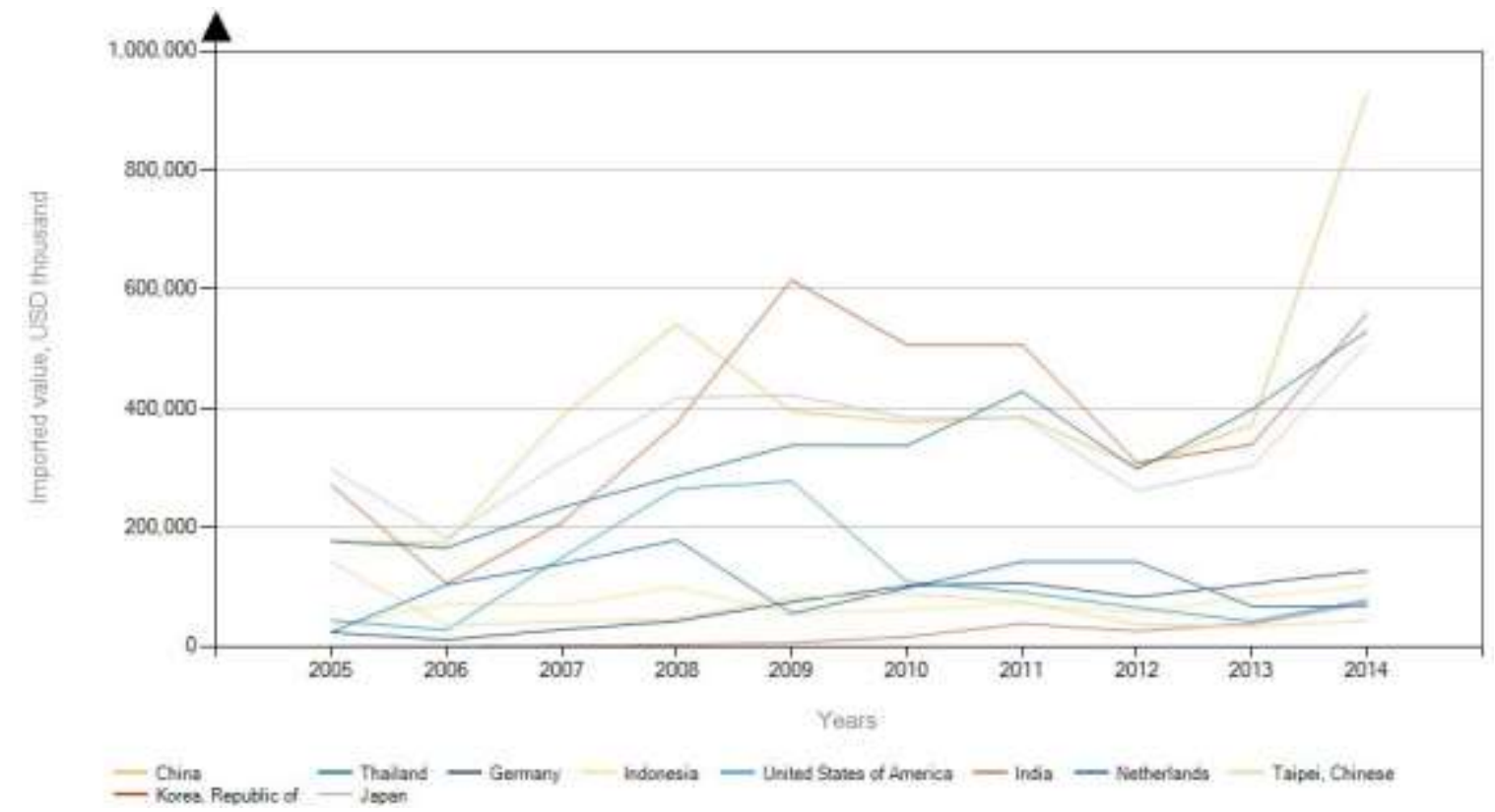

Source: Trade Map 
Table 1: List of supplying markets from ASEAN+6 for the product group HS - 87 (Vehicles other than railway, tramway) imported by Viet Nam

Unit: US Dollar thousand

\begin{tabular}{|lrrrrr|}
\hline \multicolumn{1}{r}{ Imported value } & $\mathbf{2 0 1 0}$ & $\mathbf{2 0 1 1}$ & $\mathbf{2 0 1 2}$ & $\mathbf{2 0 1 3}$ & \multicolumn{1}{c|}{$\mathbf{2 0 1 4}$} \\
\hline Worporters & $2,304,410$ & $2,437,897$ & $1,721,976$ & $1,886,317$ & $3,183,011$ \\
\hline ASEAN +6 Aggregation & $1,720,374$ & $1,851,378$ & $1,279,530$ & $1,555,345$ & $2,722,195$ \\
\hline $\begin{array}{l}\text { ASEAN +6 Aggregation } \\
\text { (as percentage in total imported } \\
\text { value from the world) }\end{array}$ & $\mathbf{7 5 \%}$ & $\mathbf{7 6 \%}$ & $\mathbf{7 4 \%}$ & $\mathbf{8 2 \%}$ & $\mathbf{8 6 \%}$ \\
\hline China & & & & & \\
\hline Korea, Republic of & 376,786 & 385,845 & 303,227 & 371,893 & 926,484 \\
\hline Thailand & 506,942 & 507,022 & 308,393 & 338,772 & 558,983 \\
\hline Japan & 337,005 & 427,782 & 297,664 & 397,849 & 529,845 \\
\hline Indonesia & 383,882 & 384,067 & 261,216 & 302,965 & 508,234 \\
\hline India & 61,475 & 72,255 & 55,991 & 83,543 & 101,591 \\
\hline Malaysia & 15,909 & 37,921 & 25,967 & 38,180 & 72,768 \\
\hline Philippines & 8,197 & 9,031 & 10,501 & 9,728 & 14,244 \\
\hline Singapore & 23,603 & 22,734 & 13,210 & 8,868 & 7,328 \\
\hline Australia & 5,179 & 3,996 & 2,715 & 2,263 & 1,243 \\
\hline Cambodia & 1,097 & 710 & 273 & 1,180 & 1,195 \\
\hline New Zealand & 112 & 8 & 346 & 96 & 259 \\
\hline Lao & 23 & 7 & 27 & 8 & 21 \\
\hline Myanmar & 164 & 0 & 0 & 0 & 0 \\
\hline Brunei Darussalam & 0 & 0 & 0 & 0 & 0 \\
\hline
\end{tabular}

Source: Authors' compilation from Trade Map database

As shown by Figure 2, among the 10 biggest supplying markets of vehicles imported by Vietnam, there are six countries belonging the proposed free trade area of ASEAN +6 , namely China, Thailand, Indonesia, India, Republic of Korea and Japan. China, Korea, Thailand and Japan that are the 4 biggest supplying markets are all participating members in ASEAN+6 negotiating FTA. It means that ASEAN+6 could be considered as a critical significant group of partner countries of Vietnam's automobile sector. Thus, the formation of ASEAN+6 free trade area is expected to bring remarkable effects on this sector of Vietnam. Table 1 supplements further statistics of imported value by Vietnam from ASEAN+6 supplying market compared to the total imported value from the world, which confirm the importance of ASEAN+6 partners to the Vietnam's trade in vehicles.

Vietnam is considered as a transitional economy, shifting from the centrally-planned economy with state subsidies to a socialist-oriented market economy. As the domestic automobile industry has not been developed, the automobile market has been still under a moderate control of the Government. However, along with the irreversible process of economic integration, this control has been relaxed. Before 2004, the Government controlled the domestic automobile market by tariffs and quotas, especially import tariffs. For example, vehicles under 12 seats were not allowed to be imported into Vietnam market 
to serve the purpose of personal consumption. Special Purpose Vehicle (SPV) import was restricted by quotas, in order to ensure competitiveness of domestic products (mainly SPV at that time). Until 2005, the CBU import duty to all vehicles for passengers and underfive-ton cargos was over $100 \%$.

Figure 3: Sales in Vietnam automobile market from 2005 to 2015

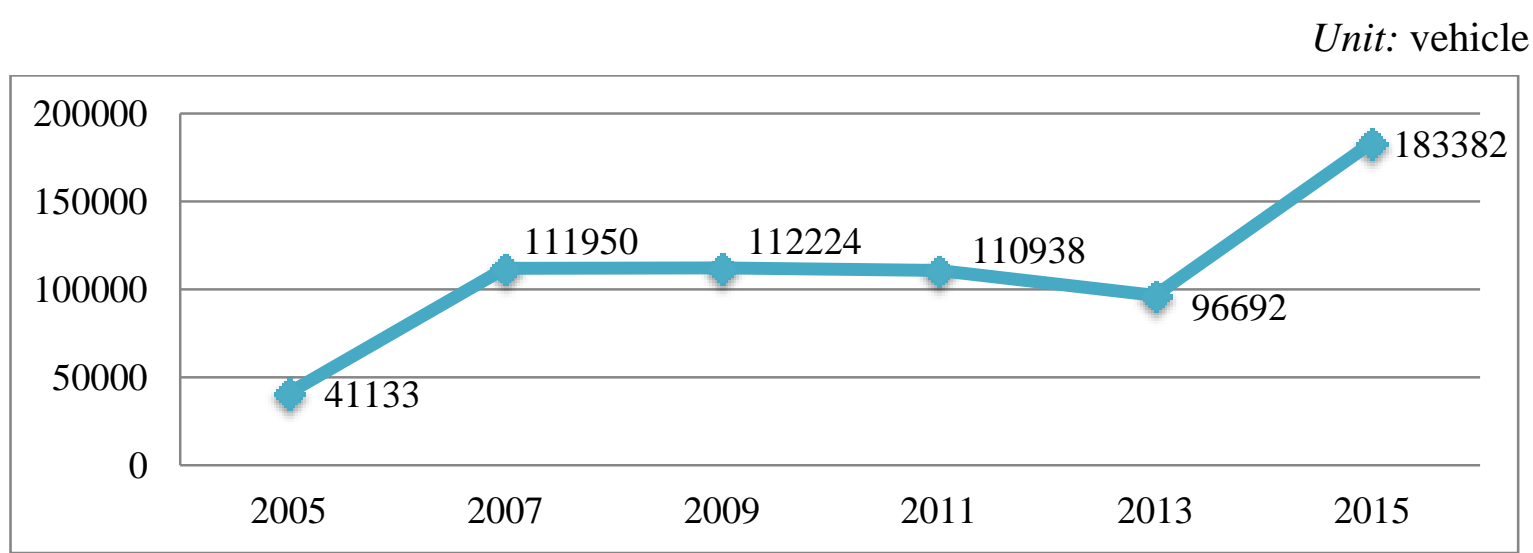

Source: OICA ${ }^{7}$ Report, 2015

In the context of globalization and economic integration, the regulatory policies of the Government are in conformity with terms and conditions negotiated and stipulated in international trade agreements. After the accession to the World Trade Organization (WTO) in 2007 and by implementing the commitments of tariff reduction, import tariffs imposed by Vietnamese government on imported automobiles started being cut. Outputs, as well as consumption quantity of vehicles in all segments have increased over the years. Sales in Vietnam automobile market increased 4.5 times in ten years (from 2005-2015), from 41,133 to 183,382 vehicles (Figure 3). It is noteworthy that demand for cars increased nearly three times (from 41,133 to 111,950) during the period from 2005 to 2007, which marks the obvious effect of the Government's policies on the automobile effects, especially the policy of tariff reduction.

\subsection{Overview of the Regional Comprehensive Economic Partnership (RCEP)}

The Regional Comprehensive Economic Partnership (RCEP) is a FTA negotiation that has been developed among 16 countries: the 10 members of ASEAN and the 6 countries with which ASEAN has existing FTAs - Australia, China, India, Japan, South Korea, and New Zealand, which is also considered as ASEAN+6. When completed, the agreement will comprise of 16 countries, which represent over $45 \%$ of the world population $(3,435$ million in 2013) and contribute about a third of the world's GDP (US\$21.3 trillion, in 2013), and make up almost 30\% of world exports (WEF, 2014, 33).

On November 2012, RCEP negotiations were launched in Phnom Penh. The $1^{\text {st }}$ round of RCEP negotiations was held on 9-13 May 2013 in Bandar Seri Begawan, Brunei.

\footnotetext{
${ }^{7}$ Organisation Internationale des Constructeurs d'Automobiles
} 
Recognizing the ASEAN Framework for RCEP, the objective of launching RCEP negotiations is to achieve a modern, comprehensive, high quality and mutually beneficial economic partnership agreement that will cover trade in goods, trade in services, investment, economic and technical cooperation, intellectual property, competition, dispute settlement and other issues among the ASEAN Member States and ASEAN's FTA Partners. RCEP will broaden and deepen current engagement that has already been achieved through the existing ASEAN+1 FTAs. Compatibility with WTO trade rules on goods and services is also a principle for RCEP negotiations.

The latest $13^{\text {th }}$ round was held in Auckland in June 2016. All RCEP countries have now submitted initial offers for trade in goods and trade in services, as well as initial reservation lists for investment. In goods, negotiators continued to engage in discussions on the way forward, in light of the statement last year that leaders were looking forward to the conclusion of RCEP negotiations in 2016. The next round is scheduled for August 2016 and will be held in Ho Chi Minh City, Viet Nam. The RCEP appears to overlap and compete with the Trans-Pacific Partnership (TPP) agreement which has become heavily influenced by the United States' economic and geopolitical agenda in the Asia-Pacific. (7 of RCEP's member governments belong to the TPP.) Additionally, China has recently decided to champion the Free Trade Area for the Asia-Pacific (FTAAP), an old USinitiated proposal to have a single free trade agreement covering all Asia-Pacific Economic Cooperation (APEC) member states.

Participating in such great FTAs like RCEP or TPP is placing numerous issues on FTA negotiating capacity of countries involved including Vietnam. Preparing well for the negotiations, which makes the actual negotiations a more manageable undertaking, is the first and foremost concern. In order to work out the negotiating objectives and strategies, it is necessary for policymakers and stakeholders to determine the potential economic effects of an FTA. Ex-ante economic assessment of an FTA may be not only an estimation of overall effects on an economy participated in the FTA as a whole but also an anticipation of impacts on particular sectors in a country that plans to join the FTA. Assessments of potential impacts of TPP are relatively extensive while those of RCEP are fairly modest, especially analyses for a specific sector of the economy, like the automobile. The more RCEP negotiation rounds Vietnam participates in, the more urgent the need to assess potential impacts of RCEP on Vietnam. Given the context, this paper is aimed at examining the potential impacts of the proposed RCEP on the automobile sector in Vietnam.

\section{Impacts of RCEP on Vietnam oil import - a partial equilibrium analysis}

\subsection{The partial equilibrium SMART model}

In FTA impact assessment, policymakers may want to focus on examining how an FTA will affect production, consumption, and trade flows in the domestic market for a single commodity. We will consider a model that is partial equilibrium. Partial equilibrium 
implies that the analysis only considers the effects of a given policy action in the market(s) that are directly affected. In general, by virtue of their simplicity, partial equilibrium models tend to be more transparent and easy to implement. Modelling is straightforward and results can be easily explained. However, due to their simplicity, partial equilibrium models may miss important interactions and feedback between various markets. Moreover, as it is only a "partial" model of the economy, the analysis is only done on a predetermined number of economic variables.

There are several partial equilibrium modelling techniques. This paper adopts the partial equilibrium model known as the SMART model - Software for Market Analysis and Restrictions on Trade - that can be used in assessing the trade, tariff revenue, and welfare effects of an FTA. This model and the simulation tools are part of the World Integrated Trade Solutions (WITS) trade database and software developed by the World Bank (WB), in close collaboration and consultation with the various International Organizations such as the United Nations Conference on Trade and Development (UNCTAD), International Trade Centre (ITC), United Nations Statistical Division (UNSD) and World Trade Organization (WTO).

\subsection{Methodology and data sources}

For the purpose of this paper, the authors define only one scenario representing a total opening of Vietnamese market to the rest of 15 RCEP negotiating partners. This should not be the exact outcome of FTA negotiations in general and RCEP negotiation in particular. Article XXIV of the GATT, under which the WTO compliance of RTAs will be established does allow for some products to be excluded from the coverage of liberalization. For RCEP, one of the Guiding Principles ${ }^{8}$ for negotiating is stated that "Taking into consideration the different levels of development of the participating countries, the RCEP will include appropriate forms of flexibility including provision for special and differential treatment, plus additional flexibility to the least-developed ASEAN Member States, consistent with the existing ASEAN+1 FTAs, as applicable." However, analysing the impact of full liberalization in a partial equilibrium framework allows distinguishing the products and sectors where the impact is greatest. Identifying the products for which the impact of liberalization is greatest may help Viet Nam to define the most "sensitive products" for which the country may want to benefit from the provision of Special and Differential treatment. The sensitivity parameters analysed here are import increase and tariff revenue loss. Therefore, the authors apply a 100 per cent tariff reduction to all products at the HS-6 level.

The WB, in close collaboration and consultation UNCTAD, ITC, UNSD and WTO have developed WITS for access and retrieval of information on various merchandise trade and tariffs data compilation maintained by various International Organizations:

\footnotetext{
${ }^{8}$ Guiding Principles (ASEAN, n.d.) were approved by Economic Ministers on 30 August 2012 and endorsed by Leaders and provide a roadmap for negotiators.
} 
- The Commodity Trade (UN Comtrade) database maintained by UNSD;

- The Trade Analysis Information System (TRAINS) maintained by UNCTAD; and

- The Integrated Data Base (IDB) and the Consolidated Tariff Schedule Data Base (CTS) maintained by WTO.

The SMART model runs on information contained in TRAINS database. SMART, therefore, uses TRAINS data for tariffs (applied tariffs) and trade values. For trade values, TRAINS data is based on the data collected in the COMTRADE database. With regard to tariffs, the SMART model uses applied tariffs as recorded in TRAINS.

\subsection{Results}

The assessment of impacts on import and tariff revenue is based on results from Market View Report and Revenue Impact Report, which are created by the SMART. Table 2 reports on the top 20 products at HS 6-digit level arranged in order of highest to lowest increase in imports to Viet Nam. A half of these 20 products will increase by more than 100 per cent in imports. The most remarkable product is 611790 (Parts of garments/of cloth accessories, of textile materials, knitted) which has the biggest import increase in terms of both absolute value $(1,425,183,125$ USD) and percentage $(803 \%)$. This product might be an important input for the sector of textile and clothing. In the context of trade liberalization, Vietnam specializes and exports more textile and clothing products - the sector which Vietnam has comparative advantage, which leads to the high demand for inputs of this sector.

Table 3 reports on simulation results for the top 20 products at HS 6-digit level arranged in order of biggest to smallest loss in tariff revenue of Vietnamese government when Vietnamese market is 100-per-cent-open to the RCEP partners. The government will lose the biggest revenue of 314,369,344 USD from import tariff imposed on the product of 271019 (Other petroleum oils and preparations). Since the gap between old weighted rate $(6.63 \%)$ and new weight rate $(1.48 \%)$ is not large, the loss of revenue may be mainly caused by the fact that this is one of the biggest import sector of Vietnam. The losses in overall budget revenue seems significant. Clearly, the country will need to enhance the fiscal base to be able to cope with the loss in tariff revenue.

It is interesting to find that there are 10 products that appear in both Table 2 and Table 3, meaning that the RCEP impacts on these products not only raise a concern to the government with regards to the revenue loss, but attract attention of the market regarding the import increase also. These most notable products are presented in the intersection of "20 highest import-increase products" collection and "20 biggest tariff revenue-loss products" collection (Figure 4). Their HS 6-digit codes are 271019, 271012, 852872, 100590, 600622, 551519, 551219, 640620, 870323, and 611790. These product groups critically deserve a cross check of their importance to the economy and a deeper assessment of RCEP's impacts on the sectors producing these products. Regarding automobile sector, the product coded 870323(Automobiles with diesel engine displacing 
more than $1500 \mathrm{cc}$ to $2500 \mathrm{cc}$ ) which belongs to the product group HS - 87 would be examined more carefully in order to understand more deeply the effect of RCEP on automobile sector in Vietnam.

Figure 4: Top 20 products with the highest increases in imported value vs. Top 20 products with the biggest losses in tariff revenue

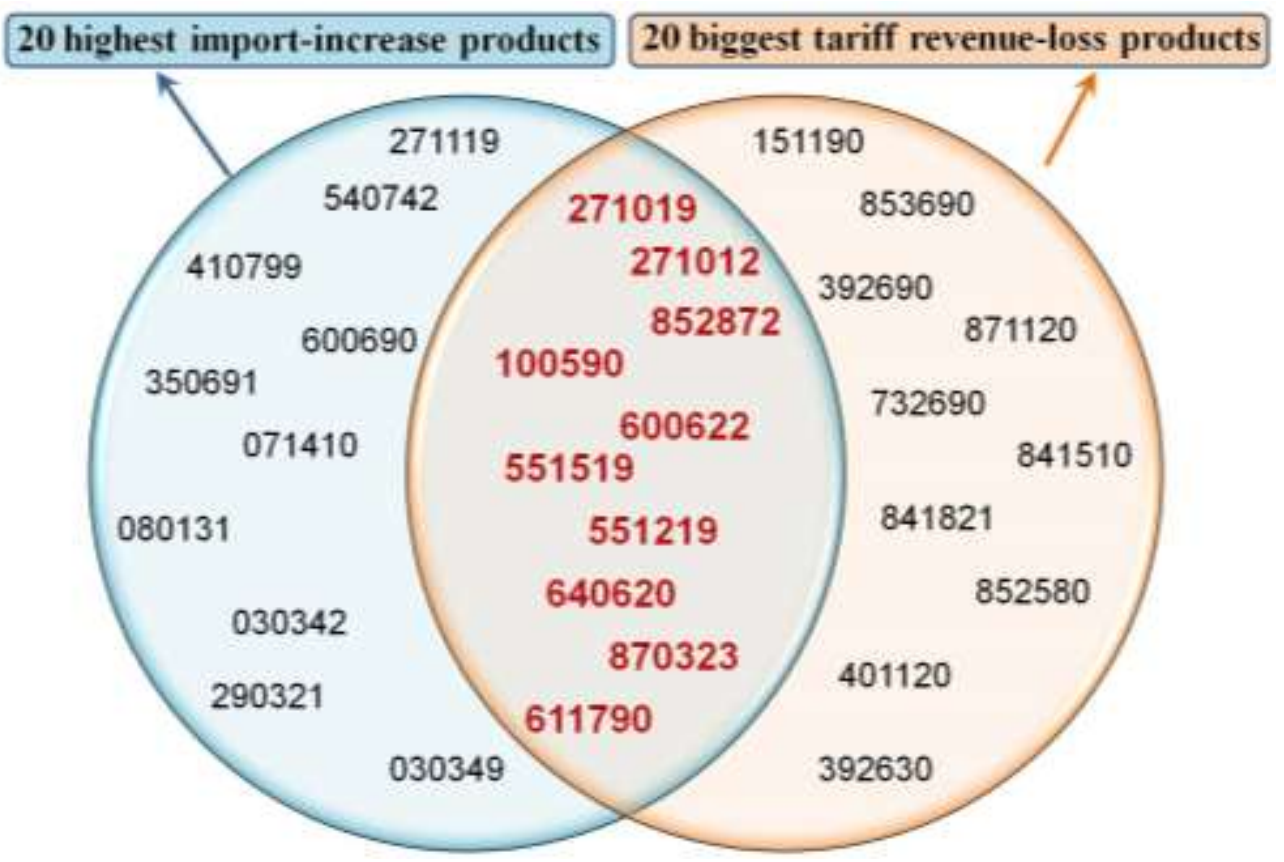

Source: Authors' compilation from SMART - WITS simulation results. 
Table 2: Increases in imports of merchandise from RCEP negotiating partners to Vietnamese market after RCEP

\begin{tabular}{|c|c|c|c|c|c|}
\hline $\begin{array}{l}\text { Ranked by } \\
\text { Import Change }\end{array}$ & $\begin{array}{l}\text { Product } \\
\text { Code }\end{array}$ & Product Description & $\begin{array}{l}\text { Imports Before } \\
\text { (USD) }\end{array}$ & $\begin{array}{l}\text { Import Change } \\
\text { (USD) }\end{array}$ & $\begin{array}{l}\text { Percentage } \\
\text { change }(\%)\end{array}$ \\
\hline 1 & 611790 & Parts of garments/of cloth accessories, of textile materials, knitted & $177,413,172$ & $1,425,183,125$ & 803.31 \\
\hline 2 & 271019 & Other petroleum oils and preparations & $6,359,577,500$ & $890,558,625$ & 14.00 \\
\hline 3 & 100590 & Maize (corn) nes & $462,771,438$ & $508,894,125$ & 109.97 \\
\hline 4 & 271119 & Petroleum gases and other gaseous hydrocarbons nes, liquefied & $289,447,469$ & $448,035,125$ & 154.79 \\
\hline 5 & 540742 & Woven fabrics, $>/=85 \%$ of nylon/other polyamides filaments, dyed, & $99,630,055$ & $426,730,719$ & 428.32 \\
\hline 6 & 551219 & Woven fabrics,containg $>/=85 \%$ of polyester staple fibres, $\mathrm{o} / \mathrm{t}$ unbl & $384,841,438$ & $321,091,188$ & 83.43 \\
\hline 7 & 600622 & Dyed cotton fabrics, knitted or crocheted, of a width of $>30 \mathrm{~cm}$ & $632,906,000$ & $280,819,344$ & 44.37 \\
\hline 8 & 410799 & Leather "incl. parchment-dressed leather" of the portions, strips or & $355,410,469$ & $209,517,750$ & 58.95 \\
\hline 9 & 600690 & Fabrics, knitted or crocheted, of a width of $>30 \mathrm{~cm}$ (excl. of artific & $219,725,438$ & $197,040,422$ & 89.68 \\
\hline 10 & 350691 & Adhesives based on rubber or plastics, nes & $83,920,320$ & $186,685,125$ & 222.46 \\
\hline 11 & 071410 & Manioc (cassava), fresh or dried, whether or not sliced or pelleted & $159,636,047$ & $180,043,344$ & 112.78 \\
\hline 12 & 640620 & Outer soles and heels, of rubber or plastics & $126,958,938$ & $162,135,547$ & 127.71 \\
\hline 13 & 271012 & Bituminous coal & $2,995,499,750$ & $160,285,297$ & 5.35 \\
\hline 14 & 080131 & Cashew nuts, in shell, fresh or dried & $321,547,281$ & $148,598,219$ & 46.21 \\
\hline 15 & 030342 & Tunas, yellowfin, frozen excluding heading No 03.04, livers and & $82,962,016$ & $142,660,766$ & 171.96 \\
\hline 16 & 290321 & Vinyl chloride (chloroethylene) & $194,141,266$ & $100,954,461$ & 52.00 \\
\hline 17 & 551599 & Woven fabrics of synthetic staple fibres, nes & $163,549,344$ & $95,079,703$ & 58.14 \\
\hline 18 & 870332 & $\begin{array}{l}\text { Automobiles with diesel engine displacing more than } 1500 \mathrm{cc} \text { to } \\
2500 \mathrm{cc}\end{array}$ & $11,859,014$ & $86,078,422$ & 725.85 \\
\hline 19 & 852872 & Reception apparatus for television, colour, whether or not & $290,416,219$ & $82,636,336$ & 28.45 \\
\hline 20 & 030349 & Tunas nes, frozen, excluding heading No 03.04 , livers and roes & $27,804,104$ & $79,824,320$ & 287.10 \\
\hline
\end{tabular}

Source: Authors 'compilation from SMART - WITS simulation results. 
Table 3: Decreases in tariff revenue of Vietnamese government after RCEP

\begin{tabular}{|c|c|c|c|c|c|}
\hline $\begin{array}{l}\text { Ranked by } \\
\text { Revenue }\end{array}$ & $\begin{array}{l}\text { Product } \\
\text { Code }\end{array}$ & Product Description & $\begin{array}{c}\text { Tariff } \\
\text { Revenue }\end{array}$ & $\begin{array}{c}\text { Revenue } \\
\text { Effect }\end{array}$ & $\begin{array}{l}\text { Percentage } \\
\text { change }(\%)\end{array}$ \\
\hline 1 & 271019 & Other petroleum oils and preparations & $421,321,990$ & $-314,369,344$ & -74.61 \\
\hline 2 & 271012 & Bituminous coal & $348,761,840$ & $-292,687,906$ & -83.92 \\
\hline 3 & 852872 & Reception apparatus for television, colour, whether or not & $101,645,670$ & $-101,550,500$ & -99.91 \\
\hline 4 & 151190 & Palm oil and its fractions refined but not chemically modified & $99,831,220$ & $-99,830,914$ & -100.00 \\
\hline 5 & 853690 & Electrical app for switchg/protec elec circuits, not exced 1,000 & $84,884,480$ & $-80,789,461$ & -95.18 \\
\hline 6 & 100590 & Maize (corn) nes & $80,985,000$ & $-64,813,410$ & -80.03 \\
\hline 7 & 600622 & Dyed cotton fabrics, knitted or crocheted, of a width of $>30 \mathrm{~cm}$ & $75,948,720$ & $-63,315,211$ & -83.37 \\
\hline 8 & 392690 & Articles of plastics or of other materials of Nos 39.01 to 39.14 nes & $57,277,570$ & $-49,086,445$ & -85.70 \\
\hline 9 & 871120 & Motorcycles with reciprocatg piston engine displacg $>50 \mathrm{cc}$ to 250 & $49,639,570$ & $-48,788,090$ & -98.28 \\
\hline 10 & 551519 & Woven fabrics of polyester staple fibres, nes & $57,012,890$ & $-48,303,727$ & -84.72 \\
\hline 11 & 732690 & Articles, iron or steel, nes & $52,159,210$ & $-43,851,891$ & -84.07 \\
\hline 12 & 841510 & Air conditioning machines window or wall types, self-contained & $41,568,090$ & $-41,405,449$ & -99.61 \\
\hline 13 & 841821 & Refrigerators, household type, compression-type & $39,556,540$ & $-39,543,414$ & -99.97 \\
\hline 14 & 551219 & Woven fabrics, containg $>/=85 \%$ of polyester staple fibres, $\mathrm{o} / \mathrm{t}$ unbl & $46,180,970$ & $-36,903,680$ & -79.91 \\
\hline 15 & 852580 & Television cameras, digital cameras and video camera recorders & $35,854,080$ & $-35,091,855$ & -97.87 \\
\hline 16 & 640620 & Outer soles and heels, of rubber or plastics & $38,087,680$ & $-34,417,313$ & -90.36 \\
\hline 17 & 870323 & $\begin{array}{l}\text { Automobiles w reciprocatg piston engine displacg > } 1500 \text { cc to } \\
3000 \text { cc }\end{array}$ & $50,608,140$ & $-34,039,328$ & -67.26 \\
\hline 18 & 611790 & Parts of garments/of clothg accessories, of textile materials,knittd & $35,482,630$ & $-33,852,867$ & -95.41 \\
\hline 19 & 401120 & Pneumatic tires new of rubber for buses or lorries & $32,147,810$ & $-30,183,547$ & -93.89 \\
\hline 20 & 392630 & Fittings for furniture, coachwork or the like, of plastics & $29,868,210$ & $-29,183,293$ & -97.71 \\
\hline
\end{tabular}

Source: Authors' compilation from SMART - WITS simulation results. 


\section{Impacts of RCEP on Vietnam oil import - an econometric analysis}

\subsection{Econometric model}

Gravity has been one of the most frequently used models in economics. An interesting fact is that, though widely used in the field of economics, gravity model based on Newton's Law of Gravitation, not an economic theory. As Murat Genç and David Law (2013), the main idea of this model is that a mass of goods or factors for production like labour, capital... from country $i, M_{i}$, is attracted to the demand for them at country $j, M_{j}$, but the distance between $i$ and $j, D_{i j}$, causes trade cost to transport the goods and makes the actual trade flow lower than it should be. $G$ indicates proportionality constant. Traditional gravity is expressed by the formula below

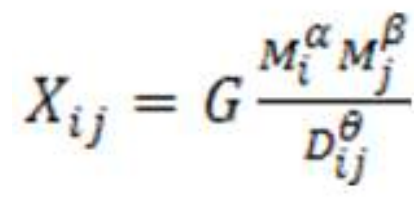

The larger the supply and demand from $i$ and $j$, the larger the trade flows; the larger the distance between the countries, the smaller the trade flows. By taking logarithms of both sides of the multiplicative form above, we have this additive form

$$
\ln X_{i j}=\ln G+\alpha \ln M_{i}+\beta \ln M_{j}-\theta \ln D_{i j}
$$

which can be estimated by OLS or other methods. Broadening the view, we can use various structures of gravity model to estimate many factors that influent trade flows among countries. $M_{i}$ and $M_{j}$ can be represented by data of GDP, GDP per capita, population...or in other words, size of the economics. $D_{i j}$ is any factor affecting trade friction, for instance, distance as in the traditional model, language, border or Governments' trade policies... There are many empirical researches based on gravity models have stated that tariff and non - tariff policies cause certain impact on trade cost. For instance, Linders et al. (2008) analysed the effects of trade barriers by using tradeweighted applied bilateral importer tariffs and dummy variable for 'low tariff and nontariff barriers', and found out both tariffs and non-tariff barriers have negative impact on the volume of trade; Winchester (2009) investigates the tariff equivalents of NTMs for New Zealand using bilateral tariffs, ad valorem export subsidy paid to exporters, and some dummy variables for NTBs and behind-the-border costs, NTBs are found to be strongly significant; Bao and Qiu (2010) examine the influence of tariffs and technical barriers to trade in case of China, using frequency index and coverage ratios to measure NTMs, the results they get are varied through different periods; Hoekman and Nicita (2011) find that tariffs, NTMs and behind-the-border transaction costs are all statistically significant determinants of bilateral trade.

Empirical studies based on gravity models state that tariffs and non-tariff measures (especially technical barriers to trade) are important factors affecting trade cost. However, those studies investigate TBTs under the form of dummy variable then converted into advalorem equivalents (AVEs), frequency ratio or coverage ratio. There has no research 
estimate TBTs with specific requirements in order to particularly analyse how the change in policies of NTMs determine trade value. This paper will dig deeper into a specific case of Vietnam's import value from RCEP countries with products in group $870323^{9}$ - Vehicle with spark-ignition internal combustion reciprocating piston engine of a cyliner capacity exceeding 1,500 cc but not exceeding 3,000 cc; using gravity model as follows:

$$
\begin{aligned}
\operatorname{lnIM}_{\mathrm{it}}{ }^{\mathrm{t}}= & \beta_{1}+\beta_{2} \ln \operatorname{lndis}_{\mathrm{ij}}+\beta_{3} \mathrm{GDP}_{\mathrm{ij}}{ }^{\mathrm{t}}+\beta_{4} \operatorname{lnPOP}_{\mathrm{ij}}{ }^{\mathrm{t}}+\beta_{5} \operatorname{lnGDPpc} \mathrm{Iij}_{\mathrm{ij}} \\
& +\beta_{6} \operatorname{lnexrate}_{\mathrm{ij}}{ }^{\mathrm{t}}+\beta_{7} \operatorname{lntariff}_{\mathrm{j}}{ }^{\mathrm{t}}+\beta_{8} \operatorname{lnNTM}_{\mathrm{j}}{ }^{\mathrm{t}}+\mathrm{u}_{\mathrm{ij}}{ }^{\mathrm{t}}
\end{aligned}
$$

The volume of trade is expected to be greater when the size of partner's economics is larger. The distance variable expresses that more distant countries have a tendency to trade less due to the rise of transportation costs. Exchange rate is expected to have negative impact on our import ${ }^{10}$. Similarity, tariff should promote trade volume when it is lessened. In case of NTMs variables, we expect the higher the numbers ${ }^{11}$ are, the more opened the policy is, which leads to a larger trade volume. Result of the model will show how traditional variables of gravity affect Vietnam's vehicle import from RCEP countries. Also, it will shed light on the possible impacts of exchange rate and especially tariff and NTMs variables on import value.

\subsection{Data description}

Data are assembled for a panel of 16 RCEP countries on average for the years 1988 to 2014 , so that the sample size is 432 . However, the actual number of observations is far smaller because of the inadequate statistic data of developing countries in RCEP. Data on imports come from UNCOMTRADE, based on statistical value of vehicle exports ${ }^{12}$ of other 15 RCEP countries in order to surmount the missing problem when Vietnam's reported data is not very adequate.

Data on tariffs come from WITS. We use two types of tariffs which are Effectively Applied Tariffs (AHS) and Most Favoured Nation Tariffs (MFN) because of the difference between them. According to WITS, MFN tariffs are what countries promise to impose on imports from other members of the WTO, unless the country is part of a preferential trade agreement. Besides, AHS is the lowest available tariff. If a preferential tariff exists, it will be used as AHS; or else the MFN applied tariff will be used. It seems to be more reasonable to use AHS in case of RCEP countries, which have widely applied preferential tariffs in most goods thanks to many regional FTAs. But AHS has a problem that it only exists when there has trade on the product, which means when a very high tariff leads to zero trade, it will not count as AHS. So we use both types of tariffs in the model. There are two ways to calculate AHS and MFN. The first one is simple average tariff, which is calculated as in the equation below:

\footnotetext{
${ }^{9}$ Code of product line in HS 6-digit

${ }^{10}$ In this study, we use indirect exchange rate.

${ }^{11}$ We use the specific number of maximum allowed quantity of emission for product 870323 , regulated by Vietnam Government.

${ }^{12}$ Value of exports is based on FOB price.
} 


$$
\tau_{\mathrm{sa}}=\sum \tau_{\mathrm{k}} / \mathrm{n}
$$

in which $\tau_{\mathrm{k}}$ is the tariff of product $\mathrm{k}, \mathrm{n}$ is the number of tariffs. The second one is weighted average tariff, calculated as

$$
\tau_{\mathrm{wa}}=\sum \mathrm{w}_{\mathrm{k}} \tau_{\mathrm{k}}
$$

in which $\mathrm{w}_{\mathrm{k}}$ is the proportion of trade of product $\mathrm{k}, \tau_{\mathrm{k}}$ is the tariff of product $\mathrm{k}$. Because we analyse the product in HS 6-digit code so these calculations show the same results. There is only difference between AHS and MFN in the model.

Data on NTMs are collected from Vietnam's legal documents, which stipulate technical requirements with product 870323 .

Other important variables such as each country's GDP, GDP per capita come from IMF. Data on population come from WB. Data on distance are taken from Google map.

The variables are listed in Table 4.

\begin{tabular}{|c|c|}
\hline Variable name & Definition \\
\hline $\ln I M$ & $\begin{array}{l}\text { Log of the vehicle' import value of Vietnam from RCEP } \\
\text { countries. }\end{array}$ \\
\hline lnexrate & $\begin{array}{l}\text { Log of the real exchange rate. An increase in this variable is } \\
\text { associated with an depreciation of Vietnamese Dong. }\end{array}$ \\
\hline lndis & $\begin{array}{l}\text { Log of the distance between the foreign country's capital and } \\
\text { Hanoi. }\end{array}$ \\
\hline $\ln \mathrm{POPi}$ & Log of a foreign country's population. \\
\hline $\ln P O P v n$ & Log of Vietnam's population. \\
\hline lnGDPpci & Log of a foreign country's nominal GDP per capita. \\
\hline $\operatorname{lnGDPpcVN}$ & Log of Vietnam's nominal GDP per capita. \\
\hline $\operatorname{lnGDPi}$ & Log of a foreign country's nominal GDP. \\
\hline $\operatorname{lnGDPvn}$ & Log of Vietnam's nominal GDP. \\
\hline $\ln \mathrm{AHS}$ & Log of the average AHS tariff level that applies in Vietnam. \\
\hline $\operatorname{lnMFN}$ & Log of the average MFN tariff level that applies in Vietnam. \\
\hline dummy & $\begin{array}{l}\text { A dummy variable taking a value of one if there is a regulation on } \\
\text { maximum allowed quantity of emission. }\end{array}$ \\
\hline $\mathrm{CO}$ & The maximum allowed quantity of $\mathrm{CO}$ emission in Vietnam. \\
\hline $\mathrm{HC} \& N O x$ & $\begin{array}{l}\text { The maximum allowed quantity of HC \& NOx emission in } \\
\text { Vietnam. }\end{array}$ \\
\hline
\end{tabular}

Table 4: Variables used in the model 
Summary statistics for the data are provided in Table 5.

Table 5: Summary statistics

\begin{tabular}{lrrrrr}
\hline Variable & Obs & \multicolumn{1}{l}{ Mean } & \multicolumn{1}{c}{ Std. Dev. } & \multicolumn{1}{l}{ Min } & \multicolumn{1}{l}{ Max } \\
\hline lnIM & 151 & 14.14294 & 2.66577 & 7.984122 & 19.13778 \\
lnexrate & 405 & 5.650958 & 2.973612 & 0.281411 & 9.978851 \\
lndis & 405 & 7.722761 & 0.7751562 & 6.171463 & 9.196306 \\
lnPOPi & 405 & 17.31113 & 2.118032 & 12.39979 & 21.03389 \\
lnPOPvn & 405 & 18.16601 & 0.1054445 & 17.96281 & 18.3234 \\
lnGDPpci & 395 & 8.243594 & 1.759465 & 3.611242 & 11.12511 \\
lnGDPpcVN & 405 & 6.173223 & 0.8875727 & 4.576338 & 7.626166 \\
lnGDPi & 395 & 4.818673 & 2.21604 & -1.287354 & 9.245371 \\
lnGDPvn & 405 & 3.61664 & 0.9868947 & 1.839438 & 5.225193 \\
lnAHS & 113 & 0.4345642 & 0.0679725 & 0.0953102 & 0.5108456 \\
lnMFN & 113 & 0.4600981 & 0.0484795 & 0.3113742 & 0.5108456 \\
dummy & 405 & 0.5185185 & 0.500275 & 0 & 1 \\
CO & 210 & 2.422857 & 0.2579482 & 2.2 & 2.72 \\
HCNox & 210 & 0.7014286 & 0.2331455 & 0.5 & 0.97
\end{tabular}

The correlation matrix among variables is provided in Table 6 .

Table 6 - Correlations matrix of the main variables

\begin{tabular}{llllllll}
\hline & lnIM & lnexrate & lndis & lnPOPi & lnPOPvn & lnGDPpci & lnGDPppcVN \\
\hline lnIM & 1.0000 & & & & & & \\
lnexrate & -0.5961 & 1.0000 & & & & & \\
lndis & 0.4821 & -0.2291 & 1.0000 & & & & \\
lnPOPi & 0.1657 & -0.1625 & 0.0630 & 1.0000 & & & \\
lnPOPvn & 0.2996 & -0.1284 & -0.1734 & 0.2886 & 1.0000 & & \\
lnGDPpci & 0.4412 & 0.1361 & 0.4428 & -0.5219 & 0.0125 & 1.0000 & \\
lnGDPpcVN & 0.2990 & -0.1276 & -0.1750 & 0.2913 & 0.9963 & 0.0121 & 1.0000 \\
lnGDPi & 0.5656 & -0.0629 & 0.4502 & 0.6778 & 0.3372 & 0.2734 & 0.3398 \\
$\operatorname{lnGDPvn}$ & 0.2993 & -0.1281 & -0.1749 & 0.2913 & 0.9969 & 0.0118 & 1.0000 \\
$\ln \mathrm{AHS}$ & -0.1776 & 0.2493 & 0.2061 & -0.0296 & -0.5439 & 0.0592 & -0.5571 \\
$\operatorname{lnMFN}$ & -0.2162 & 0.1607 & 0.0783 & -0.1992 & -0.3723 & 0.0571 & -0.4022 \\
CO & -0.2964 & 0.1107 & 0.1352 & -0.2564 & -0.8532 & -0.0413 & -0.8709 \\
HCNox & -0.2964 & 0.1107 & 0.1352 & -0.2564 & -0.8532 & -0.0413 & -0.8709
\end{tabular}




\begin{tabular}{lllllll}
\hline & lnGDPi & lnGDPvn & $\ln$ AHS & $\operatorname{lnMFN}$ & CO & HCNOx \\
\hline lnGDPi & 1.0000 & & & & & \\
lnGDPvn & 0.3396 & 1.0000 & & & & \\
lnAHS & 0.0172 & -0.5562 & 1.0000 & & & \\
lnMFN & -0.1754 & -0.3999 & 0.6353 & 1.0000 & & \\
CO & -0.3256 & -0.8695 & 0.5852 & 0.5044 & 1.0000 & \\
HCNox & -0.3256 & -0.8695 & 0.5852 & 0.5044 & 1.0000 & 1.0000
\end{tabular}

In the Table 6, correlations between Vietnam's population, Vietnam's GDP and Vietnam's GDP per capita are very large and positive. Correlations between the three variables and NTMs variables (CO and HC\&NOx) are strong and negative. $\mathrm{CO}$ and HC\&NOx is perfectly positive correlated. The remaining variables are not very strongly correlated with each other, so perfect multicollinearity might not happen.

\subsection{Regression strategy and results}

Use of panel data permits models of the form

$$
\begin{aligned}
\operatorname{lnIM}_{\mathrm{it}}{ }^{\mathrm{t}}= & \beta_{1}+\beta_{2} \ln \operatorname{lndis}_{\mathrm{ij}}+\beta_{3} \mathrm{GDP}_{\mathrm{ij}}{ }^{\mathrm{t}}+\beta_{4} \ln \operatorname{POP}_{\mathrm{ij}}{ }^{\mathrm{t}}+\beta_{5} \operatorname{lnGDPpc} \mathrm{Cij}_{\mathrm{ij}} \\
& +\beta_{6} \operatorname{lnexrate}_{\mathrm{ij}}{ }^{\mathrm{t}}+\beta_{7} \operatorname{lntariff}_{\mathrm{j}}{ }^{\mathrm{t}}+\beta_{8} \operatorname{lnNTM}_{\mathrm{j}}{ }^{\mathrm{t}}+\mathrm{u}_{\mathrm{ij}}{ }^{\mathrm{t}}
\end{aligned}
$$

where $i, j$ refers to country $i, j, t$ refers to year $t, u_{i j}$ is a time-varying idiosyncratic error. We first estimate the model using a Random Effects approach. If the model does not have heteroscedasticity, then we use POLS to estimate. If it does, we do Hausman test to choose between Random Effects and Fixed Effects approach to estimate the model. The models used in this research pass all the diagnostic tests as multicollinearity, autocorrelation, cross - sectional dependent and normal distribution of residual.

The results of the trade equation for imports of products 870323 are presented in Table 7. There are five models estimated. The first model estimates impacts of gravity variables and tariffs on import value. The second model analyses effects of not only those variables, but also dummy variable of NTMs on trade. The third model uses CO instead of dummy variables. The last two models only shows impacts of gravity variables and the two NTMs variables on import.

As this is a $\log -\log$ model, coefficients can be interpreted as elasticities, which means one percent increase in the explanation variable will be associated with a $\beta \%$ increase in the dependent variable. For dummy variable, the dependent variable will be $\beta \%$ higher when the dummy variable equals one. For the two NTMs variables without log, one unit increase in the variable will be associated with a $\beta \%$ increase in the dependent variable.

The variables GDP and GDP per capita reflect size of the economics effects. The results indicate that those variables have positive impacts on Vietnam's imports of 870323 products. A one percent increase in foreign GDP causes a 1.007\% (model 1), 0.992\% (model 2), 0.973\% (model 3), 0.938\% (model 4 and 5) increase in Vietnam's imports. 
Similarly, a one percent increase in foreign GDP per capita causes a $0.778 \%$ (model 1 ), $0.829 \%$ (model 2), $0.777 \%$ (model 3), $0.492 \%$ (model 4 and 5) increase in import value. GDP of Vietnam is also found to cause a $0.417 \%$ (model 1) increase in imports when increasing one percent. The real exchange rate has an adverse effect on vehicle imports, which is a one percent increase in exchange rate is found to cause a $0.652 \%$ (model 1), $0.643 \%$ (model 2), $0.626 \%$ (model 3), $0.716 \%$ (model 4), $0.715 \%$ (model 5) decrease in imports.

Surprisingly, both tariffs appear not to have a statistically significant effect on Vietnam's imports. Moreover, the dummy variable shows that when there have regulations on maximum allowed quantity of emission, the import increase $0.981 \%$ (model 2). CO and HC\&NOx are also found to have significant effects on dependent variable when a one percent increase in $\mathrm{CO}$ and HC\&NOx in turn causes a $1.41 \%$ (model 4) and $1.559 \%$ (model 5) decrease in imports of 870323 products.

Table 7 - Estimation results of Vietnam's import value of 870323 products

\begin{tabular}{llllll}
\hline & $(1)$ & $(2)$ & $(3)$ & $(4)$ & $(5)$ \\
& $\operatorname{lnIM}$ & $\operatorname{lnIM}$ & $\operatorname{lnIM}$ & $\operatorname{lnIM}$ & $\ln I M$ \\
\hline lnexrate & $-0.652^{* * *}$ & $-0.643 * * *$ & $-0.626 * * *$ & $-0.716^{* * *}$ & $-0.715^{* * *}$ \\
lndis & -0.383 & -0.371 & -0.064 & -0.142 & -0.142 \\
lnGDPpci & $1.007 * * *$ & $0.992^{* * *}$ & $0.973 * * *$ & $0.938^{* * *}$ & $0.938^{* * *}$ \\
lnGDPi & $0.778^{* * *}$ & $0.829 * * *$ & $0.777 * * *$ & $0.492^{* * *}$ & $0.492^{* * *}$ \\
lnGDPvn & $0.417 *$ & & & 0.087 & 0.087 \\
lnAHS & 1.315 & -0.052 & -0.249 & & \\
lnMFN & -3.402 & -3.917 & & & \\
dummy & & $0.981 * *$ & & & \\
CO & & & -0.815 & $-1.410 * *$ & \\
HC\&NOx & & & & & $-1.559 * *$ \\
Num.of obs & 78 & 78 & 69 & 95 & 95 \\
R-squared & 0.815 & 0.82 & 0.796 & 0.767 & 0.767
\end{tabular}

Notes: (***) indicates that the coefficient is significantly different from zero at the $1 \%$ significance level, (**) indicates that it is significant at the 5\% level, (*) indicates that it is significant at the $10 \%$ level.

\subsection{Interpretation}

In general, the results of gravity variables in the models are as we expected. The larger the partners' economics, the more Vietnam imports from them. The more Vietnamese dong is depreciated, the less value Vietnam imports. However, remaining variables show surprised outcomes. The models show that tariffs do not affect the import 
value. In fact, Figure 5 presents Vietnam's import value from top regional exporters and the tariffs level imposed on their vehicle products.

Figure 5: Import value and tariffs applied to some RCEP countries

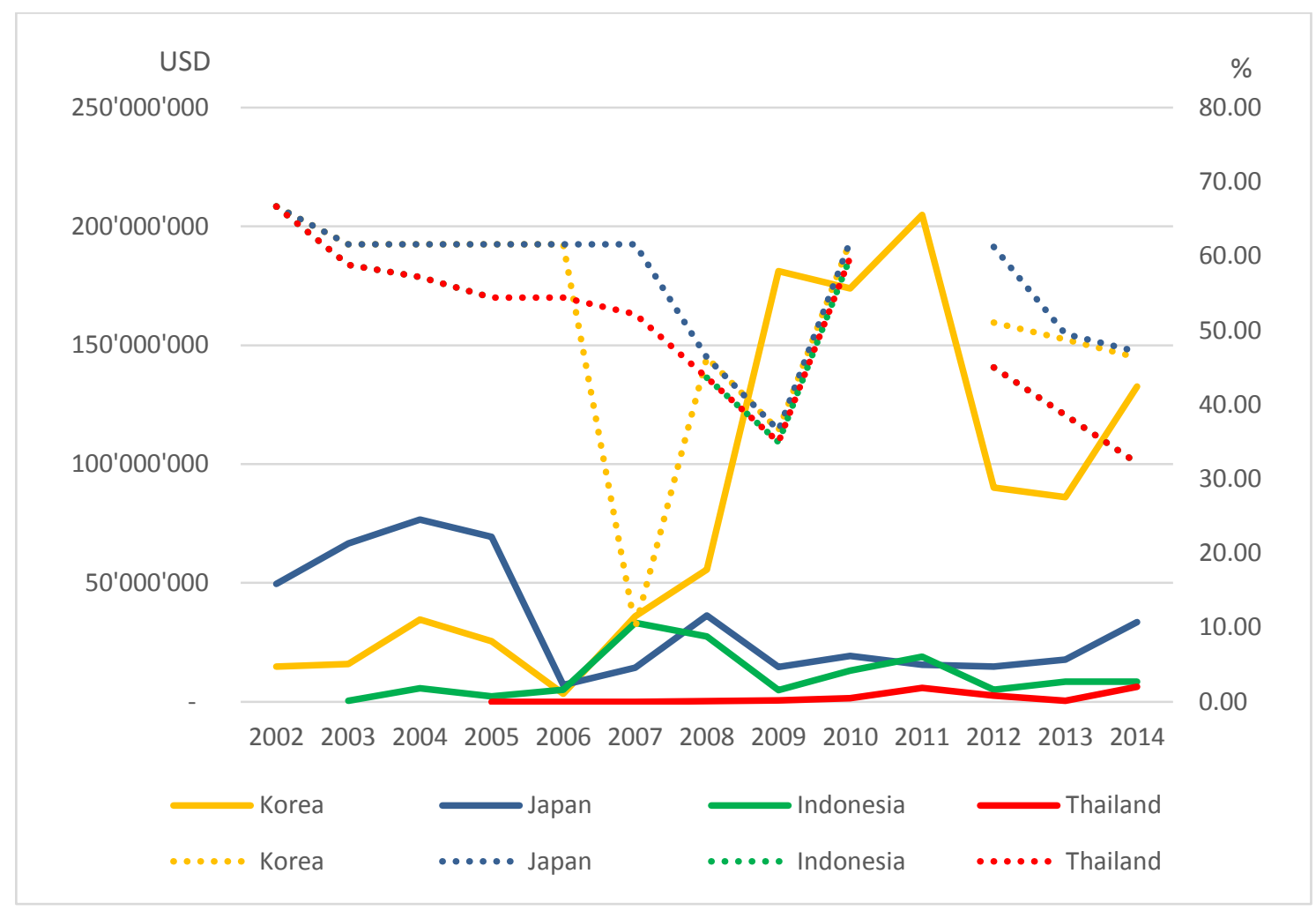

In 2007, Vietnam applied a tariff of below $10 \%$ on Korea's vehicle products, make Korea become the biggest partner. After that, the government increases the tariff but the import value from Korea is still the highest. From 2002 to 2014, tariffs on Japan's product tend to be reduced, but the import value from this country shows a down trend. Indonesia and Thailand enjoy the same preferential tariff for ASEAN countries, which is sharply lowered through the period, but imports from these countries seem to increase very slowly. A quick look at the data may explain the estimation's result. Vehicles in 870323 group are listed as discouraged import goods on Document number 1380/QD-BCT stipulated by Vietnam Ministry of Industry and Trade in 2011. They are considered as luxury goods that trigger deficit in trade balance and need controlling. Moreover, demand for luxury vehicles like cars of Vietnamese people nowadays is growing too quickly, makes traffic infrastructure overloaded and many environmental problems. That is the reason why government has used many policies to control the quantity of products in 870323 group. One of them is tariffs. These goods has been imposed the highest tariff level, but only tariffs seems to be not enough because the import value of 870323 group still increases continuously and plays an important role in Vietnam import turnover. The estimation results have already stated that. Also, as can be seen in Figure 1, there is a time lag of about more than one year in the effect of Vietnam's tariff policy. In addition, the international economics integration process requires all countries to remove tariffs for free 
trade. So that tariffs is no more an important determinant of trade nowadays. In fact, the government has used other measures to control import such as TBT, para-tariff measures or quantity-control measures... About TBT, the estimation shows adverse results to expectation, which is the stricter the barrier is, the larger import value is. This result maybe the consequence of using TBT to reduce import from big exporters. However, Vietnam, with a low level of technology, can not stipulate TBT regulations strictly enough to affect trade. At present, the government prefers para-tariff measures. To illustrate, an import car in 870323 group has suffered many kinds of tariffs, taxes and fees such as specific tariffs, Value Added Tax, Excise tax, protecting environment fee, traffic maintenance fee... Most recently, by the end of 2015, an amendment of Law on excise tax has changed the way to calculate taxed price, made the cost even higher for customers regardless of the decrease in import tariffs. Besides, prolixity in customs procedures or lack of transparent information are also barriers to import products of 870323 group. 


\section{Reference}

The World Bank, 2010, Types of tariffs, http://wits.worldbank.org/wits/wits/witshelp/Content/Data_Retrieval/P/Intro/C2.Typ es_of_Tariffs.htm

UNCTAD. (2012). Classification of Non-Tariff measures, http://ntb.unctad.org/docs/Classification\%20of\%20NTMs.pdf

The National Assembly, 2008, Law on excise tax, http://moj.gov.vn/vbpq/en/Lists/Vn\%20bn\%20php\%201ut/View_Detail.aspx?ItemID $=10509$

Bo Xiong, 2012, Three essays on non-tariff measures and the gravity equation approach to trade, Iowa State University, http://lib.dr.iastate.edu/cgi/viewcontent.cgi?article=3536\&context=etd

Xiaohua Bao, Larry D. Qiu, 2009, Quantifying the Trade Effects of Technical Barriers to Trade: Evidence from China, http://www.sef.hku.hk/apts2009/paper/A1620Xiaohua\%20Bao.pdf

WTO, 2012, World trade report 2012, Trade and public policies: A closer look at nontariff measures in the $21^{\text {st }}$ century, http://www.sef.hku.hk/apts2009/paper/A1620Xiaohua\%20Bao.pdf

Murat Genç and David Law, 2014, A Gravity Model of Barriers to Trade in New Zealand, http://www.treasury.govt.nz/publications/research-policy/wp/2014/14-05/twp14$\underline{05 . p d f}$

Tu Thuy Anh and Chu Thi Mai Phuong, 2014, On the border effect in the Regional Comprehensive Economic Partnership (RCEP), http://old.wti.org/fileadmin/user_upload/wti.org/7_SECOWTI_Project/Publications/On_the border_effect_in_the Regional_Comprehensive Economic_Partnership_TU_Thuy_Anh_and_CHU_Thi_Mai_Phuong.pdf

Tu Thuy Anh and Le Minh Ngoc, 2015, Challenges to Vietnam from the comprehensive integration into ASEAN+6: Analyses for sectors (In Vietnamese), Journal of Economics and Development, Volume 21, Number 212, National Economics University, Hanoi, Vietnam, February, 2015.

Winchester, N. (2009) Is There a Dirty Little Secret? Non-Tariff Barriers and the Gains from Trade, https://ourarchive.otago.ac.nz/handle/10523/887

Hoekman, B. and A. Nicita, (2011) Trade Policy, Trade Costs, and Developing Country Trade, http://elibrary.worldbank.org/doi/abs/10.1596/1813-9450-4797

Linders, G-J.M., M. Burger, and F. G. van Oort (2008), A rather empty world: The many faces of distance and the persistent resistance to international trade, Cambridge Journal of Regions, Economy and Society, http://cjres.oxfordjournals.org/content/1/3/439.abstract 
OICA, 2015, Production Statistics by country, http://www.oica.net/category/productionstatistics/

David Cheong, Methods for Ex Ante Economic Evaluation of Free Trade Agreements.

ADB Working Paper Series on Regional Economic Integration No. 52, Asian

Development Bank, June 2010.

Michael G. Plummer, David Cheong, and Shintaro Hamanaka, Methodology for impact assessment of free trade agreements, Publication Stock Number RPT102843, Mandaluyong City, Philippines: Asian Development Bank, 2010.

Australia, Department of Foreign Affairs and Trade, Background to the Regional Comprehensive Economic Partnership (RCEP) Initiative, 2012, available at http://www.dfat.gov.au/fta/rcep/rcep-background-paper-background.html, accessed on $2^{\text {nd }}$ August 2014.

ASEAN (n.d.), Guiding Principles and Objectives for Negotiating the Regional Comprehensive Economic Partnership., available at http://www.asean.org/images/2012/documents/Guiding\%20Principles\%20and\%200 bjectives $\% 20$ for $\% 20$ Negotiating $\% 20$ the $\% 20$ Regional $\% 20$ Comprehensive $\% 20$ Econo mic\%20Partnership.pdf

World Economic Forum (WEF), Mega-regional Trade Agreements: Game-Changers or Costly Distractions for the World Trading System, A report from Global Agenda Council on Trade \& Foreign Direct Investment, July 2014. 